\title{
From Disestablishment to Dartmouth College v. Woodward: How Virginia's Fight over Religious Freedom Shaped the History of American Corporations
}

\section{ALYSSA PENICK 이}

Dartmouth College v. Woodward (1819) has long been hailed as a landmark Supreme Court decision and a significant step in the rise of the American commercial economy. In 1817, the college sued to prevent the state of New Hampshire from modifying its colonial charter and turning the school into a public university. The Supreme Court's 1819 decision limited the power of a state legislature to invalidate a royal charter, or indeed to alter any corporate contract. ${ }^{1}$ Scholars have emphasized that "the legal structure of

1. For more on the importance of Dartmouth College, see Gregory A. Mark, "The Personification of the Business Corporation in American Law," University of Chicago Law Review 54 (1987): 1441-83; Mark D. McGarvie, "Creating Roles for Religion and Philanthropy in a Secular Nation: The Dartmouth College Case and the Design of Civil Society in the Early Republic," Journal of College and University Law 25 (1999): 52768; Francis N. Stites, Private Interest and Public Gain: The Dartmouth College Case, 1819 (Amherst: University of Massachusetts Press, 1971); and Rodney A. Smolla, The

Alyssa Penick is the 2021-2023 Age of Jefferson Postdoctoral Research Associate at the Jefferson Scholars Foundation at the University of Virginia <agpenick@ umich.edu>. She thanks the anonymous reviewers and Editor-in-Chief Gautham Rao for their valuable suggestions during the revision process. She also thanks Susan Juster, Bill Novak, Hunter Harris, Katharine Waggoner Karchner, Owen Masters, and Kristina Petersen for their advice, as well as David Tanenhaus, Laurie Wood, and Justin Simard for their comments on an early version of this piece at the Student Research Colloquium at the American Society for Legal History in 2018. Portions of this article also received instructive feedback at the Annual Meeting for the Association for the Study of Law, Culture, and the Humanities, the University of Michigan Law \& Society Rackham Interdisciplinary Workshop, and the Symposium on Roots \& Legacies of Dartmouth College v. Woodward (1819) at OU College of Law. 
the modern U.S. business corporation had its genesis" in Dartmouth College and called the case "an epochal moment in the history of American corporations." " Chief Justice John Marshall's definition of the corporation in Dartmouth College remains a touchstone for scholars and the courts today. ${ }^{3}$

However, when Daniel Webster appeared before the Court, he cast Dartmouth College as an already-settled matter of law, not a potential milestone. The famed orator maintained that Dartmouth College closely resembled a case from 4 years earlier, Terrett $v$. Taylor (1815). Terrett was a stinging federal rebuke of a Virginia Supreme Court decision, Turpin v. Lockett (1804), which had allowed the Virginia legislature to seize lands belonging to Episcopal parishes as part of religious disestablishment. ${ }^{4}$ Webster argued that the Court had already ruled in Terrett that a state legislature could not "repeal statutes creating private corporations," nor could it "repeal any part of them, or impair them, or essentially alter them, without the consent of the corporators." ${ }^{5} \mathrm{He}$ insisted that Terrett left "little to be argued or decided" in Dartmouth College. ${ }^{6}$

Despite the importance that Webster afforded to the case while arguing Dartmouth, Terrett remains little known today. ${ }^{7}$ The existing literature on Terrett primarily falls into two camps. Constitutional scholars most often discuss the case as a forerunner to Dartmouth College, but a few have found Story's opinion in Terrett "puzzling" or "gratuitous." " One

Constitution Goes to College: Five Constitutional Ideas that Have Shaped the American University (New York: New York University Press, 2011).

2. "Trustees of Dartmouth College v. Woodward," in Gale Encyclopedia of American Law, 3rd ed., Vol. 10, ed. Donna Batten (Detroit: Gale, 2010), 128; Shirelle Phelps and Jeffrey Lehman, eds., West's Encyclopedia of American Law, 2nd ed., Vol. 10 (Detroit: Gale: 2000), 122-24; and William M. Wicek, Liberty under Law: The Supreme Court in American Life (Baltimore: The Johns Hopkins University Press, 1998), 44-45.

3. See Naomi R. Lamoreaux and William J. Novak, "Corporations and American Democracy: An Introduction," in Corporations and American Democracy, ed. Lamoreaux and Novak (Cambridge, MA: Harvard University Press, 2017), 3, 9; Justice Ruth Bader Ginsburg quoted from Marshall's decision in Dartmouth College in her dissent in Burwell v. Hobby Lobby, 573 U.S. 682 (2014).

4. Turpin v. Locket, 6 Call 113 (1804).

5. Trustees of Dartmouth College v. Woodward, 17 U.S. 518 (1819), 591-92; Terrett v. Taylor, 13 U.S. (9 Cranch) (1815), 52.

6. Trustees of Dartmouth College v. Woodward, 17 U.S. 518 (1819), 591.

7. One exception is R. Kent Newmeyer, who called Justice Joseph Story's decision in Terrett "pioneering." However, Newmeyer's brief summary of the case does not clarify its circumstances or its connection to Dartmouth. See Newmeyer, Supreme Court Justice Joseph Story: Statesman of the Old Republic (Chapel Hill: University of North Carolina Press, 1985), 131-33.

8. James W. Ely Jr., "The Marshall Court and Property Rights: A Reappraisal," The John Marshall Law Review 33 (2000): 1049-50; Benjamin F. Wright, Jr., The Contract Clause of 
commenter observed that despite apparently being a Contract Clause case, "it is hard, from the case's facts, to know just what contract a state had impaired." Another interpreter argued that Terrett is best understood as a Takings Clause case whereas others suggest that Story's opinion rested on natural law with little grounding in the Constitution. ${ }^{10}$ None of these discussions adequately explain the through line from Terrett to Dartmouth. Historians of religion, on the other hand, discuss Turpin and Terrett in the context of Virginia's disestablishment without examining the cases' impact on the history of corporations. ${ }^{11}$ Studies by Mark McGarvie, Michael McConnell, and Sarah Barringer Gordon connect these fields by highlighting the intersection of state disestablishment and constitutional law, but even their studies do not resolve all of the confusion about Terrett. $^{12}$

Part of Terret's obscurity stems from its omission from Chief Justice Marshall's decision in Dartmouth College. Whereas Justices Story and Washington pointed to Terrett as a key precedent in their opinions, Marshall did not reference the case when writing on behalf of the Court. ${ }^{13}$ In fact, he cited no case law at all beyond an enigmatic statement that his decision was "equally supported by reason, and by the former decisions of this court." 14 Although acknowledging that his opinion rested on historical precedent, Marshall did not leave a trail of jurisprudential

the Constitution (Cambridge, MA: Harvard University Press, 1938), 38; and David P. Currie, The Constitution in the Supreme Court: The First Hundred Years, 1789-1888 (Chicago: University of Chicago Press, 1992), 138.

9. G. Edward White, The Marshall Court and Cultural Change, 1815-1835 (New York: Macmillan, 1988), 608.

10. Ely, Jr., 1050; William M. Wicek, The Lost World of Classical Legal Thought: Law and Ideology in America, 1886-1937 (New York: Oxford University Press, 1998), 34; Currie, The Constitution in the Supreme Court, 138-41; and Stites, Private Interest and Public Gain, 137 n.49.

11. Thomas Buckley, Establishing Religious Freedom: Jefferson's Statute in Virginia (Charlottesville, VA: The University of Virginia Press, 2013), 122-24; and H. Jefferson Powell, A Community Built on Words: The Constitution in History and Politics (Chicago: University of Chicago Press, 2005), 85-95.

12. Michael W. McConnell, "The Supreme Court's Earliest Church-State Cases: Windows on Religious-Cultural-Political Conflict in the Early Republic," Tulsa Law Review 37 (2001): 7-43; Mark McGarvie, One Nation Under Law (DeKalb, IL: Northern Illinois University Press, 2005), 152-89; and Sarah Barringer Gordon, "The Landscape of Faith: Religious Property and Confiscation in the Early Republic," in Making Legal History: Essays in Honor of William E. Nelson, ed. Daniel J. Hulsebosch and R. B. Bernstein (New York: New York University Press, 2013), 13-48.

13. R. Kent Newmeyer states that Marshall "cited" Terrett in Dartmouth, although he does not provide this citation. See Newmeyer, Supreme Court Justice Joseph Story, 132.

14. Trustees of Dartmouth College v. Woodward, 17 U.S. 518 (1819), 650. 
breadcrumbs to elucidate his thinking. This ambiguity leaves scholars with no choice but to rely on historical context to reconstruct Marshall's reasoning in Dartmouth College. More an exercise in contextualization than a standard account of jurisprudential logic, this article recovers the missing backstory to Dartmouth College by turning to what is perhaps a surprising subject: the long history of church and state in Virginia.

Two areas of early American law clarify the relationship between Terrett and Dartmouth College: corporate law and the legal disestablishment of religion. First, it is essential to recognize that the litigants in Turpin and Terrett, parish vestries, were long-standing customary corporations. In colonial Virginia, rectors, churchwardens, and vestries of the established Anglican Church were incorporated under common law. Scholarship on Terrett, and early American law more broadly, has overlooked commonlaw corporations. ${ }^{15}$ Historians of colonial Anglicanism likewise neglect the customary incorporation of the established church. ${ }^{16}$ The near absence

15. Joseph Stancliffe Davis' landmark history of American corporations briefly mentioned parishes before dismissing them as mere "quasi-corporations" rather than "true" corporations. Davis, Essays in the Earlier History of Corporations (Cambridge, MA: Harvard University Press, 1917), 6, 79-80. Recent accounts of American corporate history rely on Davis's tallies, and therefore also leave out common law corporations. Adam Winkler, We the Corporations (New York: Liveright Publishing, 2018), 4, 408 n.2. Eric Hilt, "Early American Corporations and the State," in Corporations and American Democracy, 40-42, 48, 400 n.14. Recent works that focus on the incorporation of religious societies do not explore how English common law had long offered customary incorporation to the established Anglican Church before the Revolution. Sarah Barringer Gordon, "The African Supplement: Religion, Race, and Corporate Law in Early National America," William and Mary Quarterly, 3d ser., 72 (2015): 385-422; and Amanda Porterfield, Corporate Spirit: Religion and the Rise of the Modern Corporation (New York: Oxford University Press, 2018). Other leading studies of early American corporations that do not discuss common law incorporation include Andrew M. Schocket, Founding Corporate Power in Early National Philadelphia (DeKalb, IL: Northern Illinois University Press, 2007); Jonathan Levy, Freaks of Fortunes (Cambridge, MA: Harvard University Press, 2012); Sharon Ann Murphy, Other People's Money: How Banking Worked in the Early American Republic (Baltimore: Johns Hopkins University Press, 2017); and Pauline Maier, "The Revolutionary Origins of the American Corporation," William and Mary Quarterly, 3d ser., 50 (1993): 51-84. Other works that emphasize the three types of corporations (municipal, religious, and business) leave out the distinctions between statutory and customary corporations. See Robert E. Wright, Corporation Nation (Philadelphia: University of Pennsylvania Press, 2014), 9-24.

16. None of the leading studies of colonial Anglicanism mention the corporate status of parishes under common law. Rhys Isaac, The Transformation of Virginia, 1740-1790 (Chapel Hill: University of North Carolina Press, 1982); Arthur Lyon Cross, The Anglican Episcopate and the American Colonies (New York: Longmans, Green, and co., 1902); George MacLaren Brydon, Virginia's Mother Church, 2 vols. (Philadelphia: Church Historical Society, 1947-52); and John Nelson, A Blessed Company: Parishes, Parsons, and Parishioners in Anglican Virginia, 1690- 1776 (Chapel Hill: The University 
of this topic in the literature has obscured its significance. The corporate rights of parishes were utterly familiar in the colonial Chesapeake, and the legacy of customary incorporation informed legislative debates and litigation in the Early Republic.

Second, it is essential to consider these cases within the broader context of religious disestablishment. All three cases-Turpin, Terrett, and Dartmouth - involved colonial corporations enmeshed in the fallout of post-Revolutionary disestablishment. Public opinion toward the Anglican establishment had soured in Virginia before the Revolution, and the state began dismantling the established church in 1776. The state legislature passed an act of incorporation for the newly private Episcopal Church in 1784 while also proposing a general act of incorporation for all religious societies. Had these two policies been carried into effect, Virginia's disestablishment would have resembled events in other states. However, outrage from Virginia's evangelicals led the state to backpedal swiftly. The legislature soon revoked the Episcopal Church's incorporation, prohibited any church from becoming incorporated, and confiscated parish property. No other state curbed the corporate rights of the former established church to the same degree, which made Virginia's disestablishment an important litmus test for the rights of all corporations in the early national United States.

Chief Justice Marshall had personally taken part in these debates while serving as a delegate in Virginia's legislature in the 1780s. Amidst the turmoil of Virginia's disestablishment, he opposed repealing incorporation and confiscating church property. Marshall the young legislator voiced a firm commitment to the vested rights of corporations and the irrevocability of charters decades before he would confront these issues from the bench. Recognizing the connections between Virginia's disestablishment and Dartmouth College gives scholars the context that Marshall obscured in his opinion and elucidates why Terrett anticipated Dartmouth College. ${ }^{17}$

\footnotetext{
of North Carolina Press, 2001). Phillip Bruce's work offers the only discussion of the corporate power of Virginia's parishes. Bruce, Institutional History of Virginia in the Seventeenth Century, 2 vols. (New York: G.P. Putnam's Sons, 1910), 1:77.

17. On Marshall's legal career, see G. Edward White, The Marshall Court; R. Kent Newmeyer, John Marshall and the Heroic Age of the Supreme Court (Baton Rouge: Louisiana State University Press, 2001); Jean Edward Smith, John Marshall: Definer of a Nation (New York: Henry Holt \& Co, 1996); and Charles F. Hobson, The Great Chief Justice: John Marshall and the Rule of Law (Lawrence: The University of Kansas Press, 1996). None of these works explore how Marshall's experience as a legislator during Virginia's disestablishment shaped his decision in Dartmouth College.
} 
These new perspectives on Turpin, Terrett, and Dartmouth College deepen our understanding of early American corporations in three key ways. First, these disputes reveal that the outcome of Dartmouth College was not a foregone conclusion, no matter what Webster argued. In Turpin, Virginia's highest court had authorized the legislature to disregard customary incorporation, revoke a statute of incorporation, and confiscate parish property. This decision offered a glimpse of an alternate legal landscape where American corporations existed as fundamentally communal institutions at the discretion of the legislature and charters were negotiable and revocable. The discrepancy between the Virginia court's ruling in Turpin and the United States Supreme Court's decisions in Terrett and Dartmouth underscores the competing definitions of corporations in the early republic.

Second, these cases push historians to understand disestablishment not just as a movement that secured individual rights but also as a process with significant implications for early national corporations. New Hampshire and Virginia directly challenged colonial corporate entitiescolleges and churches-while overhauling the relationship between religion and government. Legislators and the public debated church and state in the language of religious freedom, but the courts decided these cases by delineating the rights of corporations. Decisions over the legality of state disestablishmentarian policies had lasting consequences for all American corporations.

Finally, integrating customary incorporation into our narratives of early national law drastically reshapes our understanding of the rise of the corporation. Recognizing the widespread existence of common law corporations does not offer a new origin story for all American corporations; instead, it reveals the loss of a once-familiar route to incorporation before the Revolution: common law. ${ }^{18}$ Although the Court endeavored to uphold the rights of customary corporations in Terrett, common law incorporation held little value if state legislatures could simply ignore these institutions' corporate status and property claims. The weakness of common law incorporation as a mechanism for securing corporate rights strengthens our understanding of the robust protections afforded to chartered corporations in Dartmouth College. Contemporary definitions of the corporation and the

18. Traditional accounts for the rise of the business corporation focus on the shift from special acts of incorporation to general incorporation statutes, but do not address the existence of common law corporations. See James Willard Hurst, The Legitimacy of the Business Corporation in the Law of the United States, 1780-1970 (Charlottesville: The University of Virginia Press, 1970); and Louis Hartz, Economic Policy and Democratic Thought: Pennsylvania, 1776-1860 (Cambridge, MA: Harvard University Press, 1948). 
long-standing hesitancy of scholars to recognize parishes and other common law corporations as "true" corporations are a legacy of these disputes.

\section{Religious Establishment and Incorporation}

The Church of England was not a single corporation but rather owed its legal standing to numerous ecclesiastical and lay corporations, which were invested with property and rights. The corporations of the established church existed "by force of the common law... arising from the universal agreement of the whole community."19 These common law corporations could "shew no charter of incorporation," but rather derived their legal privileges and special status under the "presumed" consent of the crown and on the basis of "custom." 20 Blackstone mentioned parish churchwardens, bishops, vicars, and the king himself as examples of such customary corporations. In each case, "incorporation is so inseparably annexed to their offices, that we cannot frame a complete legal idea of any of these persons, but we must also have an idea of a corporation." ${ }^{21}$ In his Commentaries, Blackstone clarified his abstract discussion of corporate rights using accessible examples from parish life. For example, he pointed to the parish rector to illustrate the concept of a corporation sole, and invoked parish churchwardens as an example of a lay civil corporation. ${ }^{22}$ Blackstone's reliance on parochial examples underscores just how familiar these institutions were to English subjects living under the established Anglican Church.

English common law also dictated the legal standing of the Anglican establishment in colonial Virginia. The leading eighteenth-century Virginian legal writer George Webb noted that in every Virginian parish there were three distinct corporate bodies: churchwardens, vestry, and minister. Churchwardens "by the Common Law, are made a Corporation to take Care of the Goods of the Church....They are a corporation, only as to Moveables, viz to take Goods, but not Lands, for the Use of the Church." 23 The vestry purchased and maintained glebes, which were farms of at least 200 acres, "to the use of the minister of such parish, for the Time being and his successors for ever." 24 The minister was a

19. Blackstone, Commentaries on the Laws of England, 4 vols. (Oxford: Clarendon Press, 1770), I:472.

20. Ibid., I:473; 472.

21. Ibid., I:472-73.

22. Ibid., I:470-71.

23. George Webb, The Office and Authority of a Justice of the Peace (Williamsburg: Printed by William Parks, 1736), 71.

24. Ibid., 76. 
corporation sole, or a persona ecclesia, who had rights to the glebe during his tenure. The question of which parochial body held title to parish glebes would become a central issue in disestablishment, and I will return to these properties later on in this story.

Parishes organized Anglican life on both sides of the Atlantic, and these ecclesiastical bodies acted as an essential part of local government in colonial Virginia. Virginia's parish vestries and churchwardens raised an annual levy, punished moral crimes, and administered poor relief. Defenders of Virginia's Anglican establishment argued that the church promoted "publick Peace" by enforcing "Religion and Morality." 25 Political rights were tied to spiritual conformity; although religious dissenters might privately hold contrary beliefs, outwardly it was "the duty of every good Member of Society to submit...[for] the good of the whole."

Scholars of colonial Virginia have focused solely on the ways in which statutory law underwrote the power of the established church while eliding common law from their accounts. Classic accounts of church and state in Virginia detail the legislation that enforced Anglican conformity, penalized religious dissent, and knit together religion and government but make no mention of how common law conferred significant power to Anglican parishes through incorporation. ${ }^{26} \mathrm{~A}$ wide range of sources, including legal treatises, colonial legislation, and the records of lawsuits, contracts, and deeds, reveal that Virginia's vestries and churchwardens were acquisitive and litigious corporate bodies. Colonists unquestionably accepted the incorporation of parish vestries, churchwardens, and rectors under common law. Because incorporation was rare in the colonial Chesapeake, Anglican parishes were all the more powerful for holding this status.

Common law obviated the necessity of a formal act of incorporation for the established church in Virginia, but the colonial assembly recognized the corporate standing of parish vestries and churchwardens in many pieces of legislation. The assembly affirmed, for example, that vestries and churchwardens could make bylaws, disburse funds, bring lawsuits, and sign contracts. ${ }^{27}$ Like Virginia's other colonial corporations, vestries

25. "An Address to the Anabaptists Preachers Imprisoned in Caroline County," Virginia Gazette (Williamsburg: Prudie \& Dixon), February 20, 1772, 1-2.

26. For a discussion of Virginia's colonial statutes that supported the Anglican establishment and penalized religious dissent, see John Nelson, A Blessed Company: Parishes, Parsons, and Parishioners in Anglican Virginia, 1690-1776 (Chapel Hill: The University of North Carolina Press, 2001); and Isaac, The Transformation of Virginia. None of these leading studies consider how common law bolstered the Church of England.

27. William Waller Hening, ed., The Statutes at Large: Being a Collection of All the Laws of Virginia, from the First Session of the Legislature in the Year 1619 (New York: R.\&W. \& G. Bartow, 1823), 13 vols. (hereafter Hening), 2:171-72; 1:399-400; 3:151. 
were public bodies and could buy or dispose of real estate only with the assembly's approval. ${ }^{28}$ The assembly could dissolve parish vestries whom they deemed incompetent or unqualified. However, dissolving a vestry did not destroy the corporation itself or interfere with its legal rights. For example, in 1772, the assembly disbanded the vestries in St. John's Parish in King William County and St. Martin Parish in Hanover and Louisa Counties, but the parishes' property and rights remained unimpaired. $^{29}$ Virginia's parishes clearly possessed the "continuity of life" that has long been understood as an essential feature of a corporation.

Empowered by common law and affirmed in colonial statutes, parish vestries and churchwardens routinely exercised the unique rights of corporations. Churchwardens wrote contracts for every project that the parish undertook: digging wells, clearing land, or building churches. ${ }^{30}$ The corporate status of churchwardens was particularly important when executing long-term contracts; as individual churchwardens came and went, their contracts remained enforceable.

Contracts were only powerful tools if they could be enforced by the courts, and numerous parochial lawsuits appear in vestry books and county court records. ${ }^{31}$ Samuel DuVal had failed to construct a new church according to a contract he had signed with the vestry of Henrico Parish in 1771 , and he returned his advance after facing the threat of a lawsuit. ${ }^{32}$ Churchwardens often had to resort to lawsuits to recover outstanding debts. For example, in 1751, the vestry of St. Peter's Parish in New Kent County "ordered that all persons indebted to the Parish do account with the Church Wardens and Pay to their Hands the Several Sums due from them, and in failure of Payment the church wardens are required to bring suit for the recovery of the same." 33 Parishes could extend credit securely because they could recover outstanding debts in court.

28. For some examples, see Hening, 7:314-15; 9:240; 7:234; 8:365; 9:239.

29. Hening, 8:607-9.

30. C. G. Chamberlayne, ed., The Vestry Book of Petsworth Parish, Gloucester County, Virginia, 1677-1793 (Richmond, VA: The Library Board, Division of Purchase and Print, 1933), 208.

31. See examples of five parish lawsuits in the New Kent County Court listed in C.G. Chamberlayne, ed., The Vestry Book of Saint Peter's, From 1682-1758 (Richmond, VA: The Library Board, Division of Purchase and Print, 1937), 99, 112, 138-39, 253, 312. See examples of four lawsuits brought by Bristol Parish in the Prince George County Court Minute Book, 1737-1740, Mircofilm Reel 9, 94-103; 279-80; 305; 516, Library of Virginia, Richmond, VA (hereafter LVA).

32. R.A. Brock, ed., The Vestry Book of Henrico Parish, Virginia 1730-'73 (Richmond, VA: 1874$), 148$.

33. Chamberlayne, ed., The Vestry Book of Saint Peter's Parish, 312. 
Perhaps the Anglican parish's most visible exercise of corporate power was its acquisition of valuable property. Parishes amassed their wealth using an annual tax and through private donations. ${ }^{34}$ The colonial parish held wealth in many forms: taxes collected in pounds of tobacco, acres of glebe land, and the bodies and labor of enslaved people. In the colonial Chesapeake, where there were few corporations and individuals went to great lengths to preserve wealth from one generation to the next, it was not only the amount of property that parishes held but the relative security of their investments that expressed the special status and corporate power of the established church. ${ }^{35}$ Because of their privileged position as corporate entities, vestries and churchwardens held property securely in perpetuity; parishes could sell their assets more than a century later without any difficulty. ${ }^{36}$ However, dissenting congregations lacked any standing in law and instead had to vest their property in individual congregants. ${ }^{37}$ The exclusivity of common law-incorporation was yet another powerful, material advantage for the established church.

Despite Virginia's many statutes proscribing evangelical worship, the number of dissenters in Virginia continued to grow as the Great Awakening moved south in the $1750 \mathrm{~s} .{ }^{38}$ Expanding communities of dissenters began to press for incorporation to secure their property. The Virginia Assembly received its first petition for incorporation from a

34. Nelson, Blessed Company, 5.

35. Entailing land was one common method that Virginians used to preserve property across multiple generations. See Claire Priest, "The End of Entail: Information, Institutions, and Slavery in The American Revolutionary Period," Law and History Review 33 (2015): 277-319; and Holly Brewer, "Entailing Aristocracy in Colonial Virginia: 'Ancient Feudal Restraints' and Revolutionary Reform," William and Mary Quarterly, 3rd ser., 54 (1997): 307-46.

36. For Lynnhaven Parish in Princess Anne, see Princess Anne County, Deed Book 8, 532; Deed Book 9, 91; Deed Book 9, 103; Deed Book 9, 343; Deed Book 9, 343; Deed Book 14, 42, LVA.

37. For example, in Augusta County, the Presbyterian Congregation of Tinkling Spring vested lands and its church buildings in a number of individuals named as "trustees" on its deed, but these individuals lacked any standing in law to act on behalf of the church. Augusta County, Deed Book 19, No. 1, 443-44, LVA. The vulnerability of dissenters' property would surface decades later when congregations struggled to sell buildings or land to which they lacked clear title under Colonial-Era deeds. See Fincastle Presbyterian Congregation: Petition, Botetourt County, December 19, 1805, Legislative Petitions Digital Collection, LVA.

38. For more on the legal persecution of dissenters and the growth of evangelical community, see Isaac, The Transformation of Virginia; Monica Najar, Evangelizing the South: A Social History of Church and State in Early America (New York: Oxford University Press, 2008); and Jewel Spangler, Virginians Reborn: Anglican Monopoly, Evangelical Dissent, and the Rise of the Baptists in the Late Eighteenth Century (Charlottesville: University of Virginia Press, 2008). 
nonconforming church in 1774 from the Peaks of Otter Presbyterian Church in Bedford County. Although numerous congregants had made contributions to the church, "the pious intentions of such benefactors cannot be effectually carried into execution, the elders of the Church not being incorporated, so as to be capable of taking care and holding lands and Slaves for the use of the minister." The governor dissolved the colonial assembly in the turmoil of the Revolution before it could respond either affirmatively or negatively to the church's request. ${ }^{39}$

The fact that the Virginia legislature received its first petition for incorporation at the very end of the Colonial Era shows just how effectively Virginia's laws had dissuaded dissenters from settling in the colony or seeking legal rights. The timing is particularly striking when compared with other Anglican colonies. The New York and South Carolina legislatures rejected numerous petitions for incorporation from dissenting congregations throughout the eighteenth century. ${ }^{40}$ In Maryland, the legislature's mortmain statutes denied Catholics and Protestant dissenters the ability to incorporate; the parishes of Maryland's established Anglican Church, however, held their property under common law incorporation. ${ }^{41}$ Virginia's growing community of dissenters was just beginning to protest against their inability to incorporate on the eve of the Revolution.

\section{Revolutionary Disestablishment}

The expansion of religious freedom was not just an ideological struggle; it was also a legal quandary for newly independent states. The corporate rights of churches, and by extension all private corporations, vis-à-vis the state government became a central question in these deliberations. Many states sought to level the playing field among denominations by passing general statutes of incorporation that allowed all religious societies to become incorporated. ${ }^{42}$ Not so in Virginia, where the battles over incorporation would ultimately lead to a radical rejection of any form of religious incorporation. The

39. Journals of the House of Burgesses of Virginia, 1773-1776 (hereafter JHBV), May 17, $1774,103$.

40. See Patrick J. Dignan, History of the Legal Incorporation of Catholic Church Property in the United States, 1784-1932 (New York, P. J. Kenedy \& Sons, 1935), 27-30; Cross, The Anglican Episcopate, 181; Susanna Linsley, "The American Reformation: The Politics of Religious Liberty, Charleston and New York 1770-1830" (PhD diss., The University of Michigan, 2012), 37-50.

41. Dignan, History of the Legal Incorporation, 35-40.

42. "The First Disestablishment: Limits on Church Power and Property Before the Civil War," University of Pennsylvania Law Review 162 (2014): especially 316-32. 
exclusive legacy of the establishment's customary incorporation and its material wealth hung over these post-Revolutionary debates in Virginia.

Virginia's Anglican establishment faced significant backlash during and after the Revolution. The increasing number of religious dissenters, along with intense anti-British sentiment during the war, eroded support for the religious establishment following the outbreak of the Revolution. ${ }^{43}$ In 1782, the American branch of the Anglican Church established itself as the Protestant Episcopal Church, but a new name was not enough to convince wary Americans to rejoin its ranks. Political leaders inclined to enlightenment rationalism, such as Thomas Jefferson and James Madison, allied with evangelicals to initiate the piecemeal process of dismantling the established church. The legislative program of disestablishment began in 1776 with the passage of the Virginia Declaration of Rights, which guaranteed free exercise. Over the next decade, a host of colonial laws that had empowered the Anglican Church and penalized dissenters were overturned. The 1786 Virginia Statute for Establishing Religious Freedom extended the promise of religious liberty. ${ }^{44}$ Written by Jefferson and championed by Madison, the act abolished state financial support for religion, repealed religious tests, and overturned laws that had curbed free exercise of religion.

Incorporation remained front and center in Virginia's debates over disestablishment precisely because it had been a closely guarded privilege of the established church. In May of 1784, the United Clergy of the Presbyterian Church sent a memorial to the assembly protesting that "the episcopal church is actually incorporated, and known in law as a body, so that it can receive and possess property for ecclesiastical purposes, without trouble or risk in securing it, while other Christian communities are obliged to trust to the precarious fidelity of trustees chosen for the purpose." ${ }^{45}$ Virginia's Presbyterian clergymen argued that customary incorporation still bestowed the Episcopal Church with substantial power, and therefore they sought an act of incorporation for their church. A few weeks later, the clergy of the Episcopal Church also petitioned the legislature for an act of incorporation. The formerly established church worried that their change in "appellation" would

43. For more on how Virginia's dissenters challenged the Anglican establishment, see Thomas Buckley, Church and State in Revolutionary Virginia, 1776-1787 (Charlottesville: University Press of Virginia, 1977); and John Ragosta, Wellspring of Liberty: How Virginia's Religious Dissenters Helped Win the American Revolution and Secured Religious Liberty (New York: Oxford University Press, 2010).

44. Hening, 12:84.

45. Clergy of the Presbyterian Church: Petition, May 26, 1784, Legislative Petitions Digital Collection, LVA. 
lead to "cavils. . disputes and litigations" over parish property and hoped that the state would reaffirm their customary corporate rights under a formal act of incorporation. ${ }^{46}$

The Committee for Religion in the Virginia House of Delegates endorsed the Episcopal Church's request for incorporation while also recommending a general act of incorporation to benefit "all other religious societies."47 The legislature passed an act incorporating the Episcopal Church in the fall session of 1784. James Madison and John Marshall, both members of the House of Delegates, voted in favor of the law, which reaffirmed parishes' claims to their pre-Revolutionary property and recognized the formerly established church as a newly reorganized, private corporation. ${ }^{48}$ The legislature tabled general incorporation and postponed voting on a general assessment until the following year. ${ }^{49}$

Critics initially attacked the specifics of the 1784 Incorporation Act without raising fundamental objections to religious incorporation. John Blair Smith, a leading Presbyterian minister, wrote to Madison during the summer of 1784 that some form of incorporation could "have been extremely proper," but that the specific terms of the 1784 act had made the "Church a mere political machine, which the State may regulate at pleasure." 50 Madison concurred and expressed concerns that the law kept the Episcopal Church under legislative "oversight." However, he acknowledged that "the necessity of some sort of incorporation for the purpose of holding and managing the property of the Church could not well be

46. Clergy of the Protestant Episcopal Church: Petition, June 4, 1784, Legislative Petitions Digital Collection, LVA.

47. Journal of the House of Delegates of the Commonwealth of Virginia; Begun and Held in the City of Richmond, in the County of Henrico, on Monday, The Third Day of May, in the Year of Our Lord One Thousand Seven Hundred and Eighty-Four (Richmond: Commonwealth of Virginia, 1828), 43.

48. For the text of the incorporating act, see Hening, 9:532-37. For the record of votes, see Journal of the House of Delegates of the Commonwealth of Virginia; Begun and Held in the City of Richmond, in the County of Henrico on Monday, The Eighteenth Day of October, in the Year of Our Lord One Thousand Seven Hundred and Eighty-Four (Richmond: Commonwealth of Virginia, 1828), 79.

49. The prospect of general incorporation for religious societies was proposed in June and again in November of 1784, but the House never voted on a specific bill. The issue of the general assessment was postponed until the following year. See Journal of the House of Delegates of the Commonwealth of Virginia; Begun and Held in the City of Richmond, in the County of Henrico on Monday, The Eighteenth Day of October, in the Year of Our Lord One Thousand Seven Hundred and Eighty-Four, 27, 82.

50. John Blair Smith to James Madison, June 21, 1784, Founders Online, National Archives, https://founders.archives.gov/documents/Madison/01-08-02-0043 (accessed April 4, 2019).

51. James Madison to Thomas Jefferson, January 9, 1785, Founders Online. 
denied." Despite his reservations, Madison was willing to support incorporation in order to prevent any sort of religious tax from passing, which he viewed as "a much greater evil." 52

Presbyterians and Baptists organized a petitioning campaign to demand a repeal of the Incorporation Act during $1786 .{ }^{53}$ Echoing Smith and Madison, evangelical petitioners argued that the Act of Incorporation had made the legislature "the Head of that church" in violation of the state constitution. The other chief objection to the 1784 law was that it allowed the Episcopal Church to retain "the Glebes, churches, surplus money and other Things," which ought to have become "the Property of the Publick." ${ }^{54}$ Evangelicals sent petition after petition calling for the repeal of the 1784 Incorporation Act and insisting that parish property belonged to the entire Virginian public whose taxes had funded its purchase. Episcopalians, on the other hand, argued that revoking incorporation threatened the fundamental "principles of the Revolution" by threatening the security of their private property. ${ }^{55}$

In order to build as comprehensive a case as possible for repealing the 1784 Act of Incorporation, evangelical petitioners mounted arguments against any form of religious incorporation. An appeal sent by the Baptist General Committee declared that churches could only be regulated "by the Law of God and not the Law of the State; by the acts of the Apostles, and not by the Acts of an Assembly." 56 The petitioners invoked Article 16 of Virginia's Declaration of Rights to argue that if religion "can be directed, only by reason and conviction; not by force and violence, we cannot see with what propriety the General Assembly could incorporate the Protestant Episcopal Church." ${ }^{57}$ These wide-ranging criticisms of the 1784 Act gave rise to a fundamental opposition to all forms of incorporation for religious societies, a development that did not happen in other states. ${ }^{58}$

In the midst of these debates over repeal, Madison heard the expertise of two of Virginia's leading legal minds: Edmund Randolph, then Governor of Virginia and future United States Attorney General and Secretary of State, and John Marshall, member of Virginia's legislature and future

52. James Madison to Thomas Jefferson, January 9, 1785, Founders Online.

53. H.J. Eckenrode, Separation of Church and State in Virginia: A Study in the Development of the Revolution (Richmond: Virginia State Library, 1910), 120; Buckley, Church and State in Revolutionary Virginia, 168.

54. Eckenrode, Separation of Church and State in Virginia, 120

55. Inhabitants of St. Asaph's Parish: Petition, Caroline County, December 4, 1786, Legislative Petitions Digital Collection, LVA.

56. Eckenrode, Separation of Church and State in Virginia, 121.

57. Ibid.

58. Gordon, "The First Disestablishment," especially 319-44. 
Chief Justice of the United States Supreme Court. ${ }^{59}$ One brief page of notes remains extant from this meeting, which has largely escaped the attention of constitutional scholars. ${ }^{60}$ Although hurried and abbreviated, the document captures Randolph and Marshall's resounding objections to repealing a charter of incorporation. The men characterized charters as "irrevocable" and compared rescinding incorporation to the "tyrannical acts" of Great Britain before the Revolution. As Marshall said, "Laws of incorp[oratio]n. [are] distinct from general laws \& not like them repealable: being compacts between two parties" and elaborated that a "vested Right of any sort cannot be touched." Whereas evangelicals were focused on the righteousness of repeal, Marshall and Randolph focused on the legality of revoking an act of incorporation. ${ }^{61}$

Although Marshall opposed repeal, his comments suggested a way forward for opponents of the law. The Virginia Declaration of Rights proclaimed that no "compact" could deprive individuals of certain inalienable rights. Marshall intimated that, "if sense of people, Legislature may interpose-sense not yet expressed by majority." Only if the people's fundamental rights had been betrayed by a corporate charter could the legislature "interpose" on their behalf and justifiably revoke incorporation. More than any other line in the document, Marshall's final observation revealed that this discussion was not abstract, but rather concerned the 1784 Act of Incorporation. He argued that most Virginians did not understand the law as a violation of their constitutional rights; therefore, a repeal was not permissible. More than 30 years before Dartmouth College, the turmoil of Virginia's disestablishment prompted Marshall to consider the vested property of corporations and to answer the question of whether a legislature could repeal incorporation. ${ }^{62}$

Unmoved by Marshall's arguments, Madison voted to repeal the act of incorporation for the Episcopal Church after passing the Statute for Religious Freedom. ${ }^{63}$ Virginia's evangelicals had not only succeeded in overturning the specific law but in reshaping the constitutional definition

59. Although Randolph is simply called "Mr. R," the context of the document and Marshall and Randolph's legal partnership make Randolph's identity almost certain. James Madison, "Notes on Charters of Incorporation, [January?] 1786," Founders Online.

60. One of the only previous citations to this document appears in Mary Sarah Bilder, "James Madison, Law Student and Demi-Lawyer," Law and History Review 28 (2010): 411 n.116.

61. Madison, "Notes on Charters of Incorporation," Founders Online.

62. Virginia Declaration of Rights, Section 1. The Avalon Project at Yale Law School. https://avalon.law.yale.edu/18th_century/virginia.asp (accessed October 12, 2020); and Madison, "Notes on Charters of Incorporation," Founders Online.

63. Hening 12:266-67. 
of a religious establishment to include religious incorporation. Their advocacy of such a radical view is best understood in light of the long history of the Anglican Church's exclusive access to incorporation. After the repeal of the Incorporation Act, no other religious societies became incorporated in the state, and the legislature formally enacted a prohibition against religious incorporation in $1798 .{ }^{64}$ In 1851 , the commonwealth formally amended its Constitution to add this provision, which stood in place until 2002. ${ }^{65}$ The hostility toward religious incorporation in Virginia was exceptional, which explains why the state's distinctive policies would become significant test cases for the rights of corporations.

Evangelicals continued to press the legislature to seize Episcopal parish property. John Marshall and Edmund Randolph both voted in favor of a resolution in 1789 to prevent any further discussion of the glebes. The 1789 resolution presented a legal rationale against confiscation by declaring that the dispute over the glebes was "not of a religious nature" but ought to be settled by "the rules of private property." Glebes, churches, and chapels that had been purchased, donated, or acquired through "grants from the King of England," had been "vested in bodies which were capable in law of taking and holding them to their own use, and which actually did take and hold them to that use." Confiscation by the commonwealth would amount to "an unconstitutional invasion of right" and a "usurpation in the Legislature." The legislature sought to "guarantee" that parishes' property would "be inviolably preserved." Marshall's support for this declaration foreshadowed the decision in Terrett, and its specific discussion of royal grants gestured toward his logic in Dartmouth College. ${ }^{66}$

However, the Baptists eventually won this battle. In 1798, Virginia repealed portions of six acts from the 1770s and 1780s that had allowed the Episcopal Church to retain parochial property, which the legislature now deemed "inconsistent with the principles of the constitution, and of religious freedom, and manifestly tend[ed] to the re-establishment of a

64. T. Ritchie, ed., The Revised Code of the Laws of Virginia (Richmond: Commonwealth of Virginia, 1819) (hereafter Revised Code), 79.

65. Virginia Constitution (1851), article 32. See Falwell v. Miller, 203 F. Supp. 2d 624, 632-33 (W.D. Va. 2002) ("The portion of $\S 14(20)$ of Article IV of the Constitution of Virginia which reads, 'The General Assembly shall not grant a charter of incorporation to any church or religious denomination..., violates Plaintiffs' First Amendment rights to the free exercise of their religion made applicable to the States by the Fourteenth Amendment").

66. Journal of the House of Delegates of the Commonwealth of Virginia; Begun and Holden in the City of Richmond, in the County of Henrico, on Monday, The Nineteenth Day of October, in the Year of Our Lord One Thousand Seven Hundred and EightyNine (Richmond: Commonwealth of Virginia, 1828), 83-84, 113. 
national church."67 Although the 1798 law laid the philosophical groundwork for the legislature to claim all parish property, it was not until 1802 that the legislature authorized a specific plan for confiscation when it passed the Glebe Act. This statute asserted "that all property formerly belonging to the Church, of every description, devolved on the good people of this commonwealth, on the dissolution of the British government here." Sixteen years after declaring the Episcopal Church independent from the state and preserving its property, the assembly stripped the denomination of its glebe property. ${ }^{68}$

\section{Challenging Virginia's Glebe Act}

Two of Virginia's most idiosyncratic disestablishmentarian policies - its revocation and prohibition of religious incorporation and its seizure of church property - set the state on a collision course to confront parishes over their corporate rights. The Virginia Supreme Court and the United States Supreme Court ultimately diverged sharply over the legality of the 1802 Glebe Act and the state's disestablishmentarian program. The discrepancy in their opinions exposed ideological fault lines among leading constitutional thinkers about the rights of a corporation and the definition of religious establishment.

The battle over the glebes swiftly moved from Virginia's legislature to the courts as Episcopalians around the state sought injunctions to avert the seizure of their property. A challenge to the law reached the Virginia Supreme Court in 1802 after the vestry of Manchester Parish sued to prevent the Chesterfield County Overseers of the Poor from selling their glebe in a case known as Turpin v. Lockett (1804). ${ }^{69}$ Proceedings in Turpin halted the sale of glebe lands as the state's highest court deliberated. In Turpin, the Virginia Supreme Court considered incorporation twice over. First, they weighed whether some of Virginia's oldest and most familiar customary corporations - parish vestries, churchwardens, and ministershad withstood a republican revolution and religious reformation. Second, the court had to rule on whether the state legislature had the right to revoke incorporation after chartering the Episcopal Church as a private body.

The Virginia Supreme Court's chief justice was Edmund Pendleton, a lifelong vestryman in Caroline County and a staunch Episcopalian. ${ }^{70}$

67. Revised Code, 1:78-79.

68. Ibid., 1:79-80.

69. Turpin v. Locket, 6 Call 113 (1804).

70. On Pendleton's legal career, see David John Mays, Edmund Pendleton, 1721-1803: A Biography (Cambridge, MA: Harvard University Press, 1952). 
Pendleton had close ties to the Episcopal Church, and the public assumed that he would rule in favor of the vestry and strike down the law. However, the day before delivering his opinion in court, the 82-year-old justice died, supposedly with an opinion striking down the Glebe Act beside him. ${ }^{71}$ The resulting mistrial led to a second trial. Pendleton's successor, St. George Tucker, was a leading figure in the rising generation of Virginian Republicans and had quietly signaled his approval of the Glebe Act in order to secure his election as a justice by the legislature. ${ }^{72}$ Ideologically aligned with Jefferson and Madison, Tucker reached a radically different conclusion than Pendleton might have. Tucker was sympathetic to the Episcopal Church's predicament and expressed disappointment that the question of the glebes had "been agitated" with such hostility. But he ultimately dismissed the vestry's suit and upheld the Glebe Act as lawful under Virginia's Constitution. ${ }^{73}$

Tucker's decision began with a review of common law and colonial statutes to determine the corporate standing of the vestry. Tucker had recently published a revised version of Blackstone's Commentaries and was widely viewed as one of the nation's leading experts on common law. Under both colonial statute and common law, "the vestries in Virginia were a body politic, capable of purchasing and holding lands for the use of the ministers of their respective parishes; and capable of a perpetual succession," and "the legal titles to all the glebe lands in Virginia" were "at the period of the revolution vested in the vestries." But the Revolution had abolished every vestige of the monarchial government and "the mere act of rejecting the king and the ancient constitution of the colony, and adopting one totally different therefrom, did operate an immediate dissolution of every part of the body politic connected with, and dependent upon, the ancient constitution, or form of government." Therefore, vestries no longer held "their ancient rights" after Virginia declared independence. ${ }^{74}$ For Tucker, the Revolution had destroyed the conditions necessary for customary incorporation. The rights secured under common law had relied on the king's

71. Historians do not have Pendleton's decision, but his views on the glebes were well known. See Mays, Edmund Pendleton, 337-45; Mays, The Letters and Papers of Edmund Pendleton, 1734-1803 (Charlottesville: Published for the Virginia Historical Society by the University Press of Virginia, 1967), 2:637-42.

72. Buckley, Establishing Religious Freedom, 119-20. For more on the connection between Tucker's political views and his jurisprudential philosophy and outlook as a jurist, see Christopher Doyle, "Judge St. George Tucker and the Case of Tom v. Roberts. Blunting the Revolution's Radicalism from Virginia's District Courts," The Virginia Magazine of History and Biography 106 (1998): 419-42.

73. Turpin v. Locket, 6 Call 113 (1804), 129. For more on Tucker's connection to the case, see Buckley, Establishing Religious Freedom, 116-22.

74. Turpin, Call 113 (1804), 113; 129; 139; 148. 
consent and therefore had not survived the political revolution. Tucker's conclusion portended a fatal blow to common law corporations in the new republic; customary incorporation was a precarious mechanism for securing rights and property if states could simply ignore it.

But what was the fate of the many laws concerning the legal status and property of the Episcopal Church after independence? Tucker argued that the 1784 Act of Incorporation had amounted to an "entirely new, and essentially different, constitution of incorporation."75 Parish ministers and vestries had accepted "a private foundation" under this act, which "must be construed as a total surrender of their former state." cluded, "the ancient vestries were dissolved, either by the change of government, or by the act for incorporating the protestant episcopal church: and that the new bodies corporate. ..were private incorporations, essentially differing from the former, and owing their existence and their rights, solely to that act of the legislature."77 According to Tucker, the Revolution had destroyed the conditions necessary for customary incorporation, and the legislature had reconstituted vestries as private corporations.

Tucker's Turpin opinion then dealt quickly with the question that would occupy the Court's attention in Dartmouth College: did the legislature have the authority to dissolve a private corporation? Tucker made two arguments to justify the dissolution of private corporations. First, he cited the Henrician dissolution of the monasteries during the English Reformation and the colonial assembly's ability to dissolve vestries as proof that "such corporations may be dissolved by the authority of the parliament or legislature alone."78 Of course, these establishmentarian precedents provided a shaky framework for the post-revolutionary relationship between corporations and the state. By narrowly addressing the Glebe Act in the context of religious reformation, Tucker ducked the underlying question of whether a legislature could revoke the incorporation of a private religious society in the absence of an established church, or the charter of any private corporation for that matter. Tucker offered a second, more sweeping defense of the legislature's right to dissolve private corporations by distinguishing between the rights of people and corporations. The state could not rescind grants made to individuals in their "natural capacity," but "where the legislature creates an artificial person, and endows that artificial person with certain rights and privileges, either in respect to property, or otherwise, this must be intended as having some relation to the community

75. Turpin v. Locket, 6 Call 113 (1804). 10 Va. 113, 144.

76. Ibid.

77. Turpin v. Locket, 10 Va. 113, 148.

78. Turpin v. Locket, 10 Va. 113, 150. 
at large."79 Tucker contended that the basis for the legislature to grant rights and property to a corporation was fundamentally public; accordingly, the legislature retained the power to modify the relationship between the corporation and the community. If the legislature deemed a prior grant "merely impolitic," it retained the power to dissolve a corporation and seize its property. ${ }^{80}$ Whereas Marshall had required unconstitutionality as grounds for revoking incorporation, Tucker set the bar far lower.

This decision not only allowed the legislature to expropriate the glebes but also asserted that doing so reversed earlier unconstitutional grants of property. Tucker accepted the arguments made by evangelicals over the previous 15 years that the legislature had violated the provision for religious freedom and the prohibition against emoluments in Virginia's Declaration of Rights by preserving parish property and incorporating the Episcopal Church. The Glebe Act of 1802 would stand. ${ }^{81}$ Within weeks, counties began confiscating parish lands across the state. Over the course of the next several decades, more than 35,000 acres, dozens of enslaved men and women, and other glebe property would be seized. ${ }^{82}$ Although the Glebe Act had not authorized the sale of churches or their contents, counties auctioned off churches, pews, bells, communion silver, and books. However, the question of parish rights and property wound up before the courts again a decade later.

\section{The Supreme Court's Reproach}

The controversy over Virginia's confiscation of the glebes landed before the Supreme Court in the case of Terrett v. Taylor (1815). The court's decision in Terrett refuted Turpin's logic at every step, despite never mentioning the earlier Virginian case by name. Whereas Tucker had granted the legislature significant latitude to regulate private corporations, the Court used Terrett as an opportunity to assert the independence of private corporations vis-à-vis state legislatures, and defended corporations' "indefeasible and irrevocable" titles to their property. ${ }^{83}$

The conflict in Terrett $v$. Taylor (1815) resembled the earlier Turpin v. Lockett in many ways. In Terrett, the Vestry of Christ Church in

79. Turpin v. Locket, 10 Va. 113, 156.

80. Ibid.

81. "The Virginia Declaration of Rights," Section 16 and Section 4.

82. My dissertation has traced and tracked Virginia's glebe confiscations. See Alyssa Penick, "The Churches of Our Government: Parishes, Property, and Power in the Colonial and Early National Chesapeake" (PhD diss., The University of Michigan, 2020).

83. Terrett v. Taylor, 13 U.S. (9 Cranch) (1815), 50. 


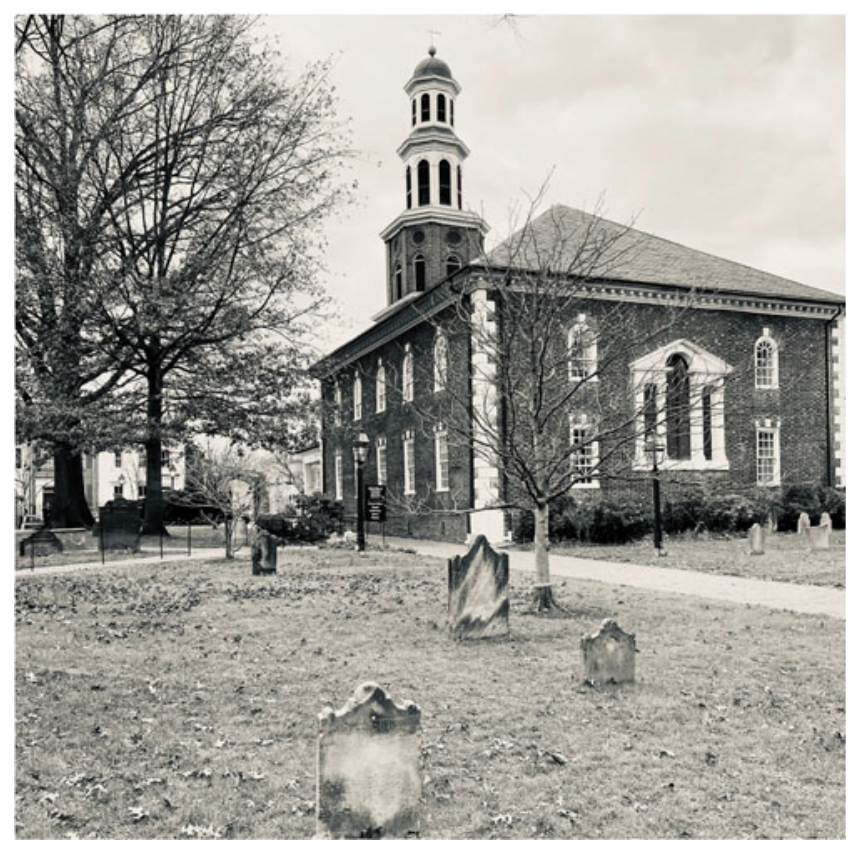

Figure 1. Christ Church in Alexandria, Virginia in 2020. Photograph by the author.

Alexandria sought to block the Fairfax County, VA Overseers of the Poor from seizing its 517-acre glebe (see Figure 1). In the colonial era, Fairfax Parish had stretched along the Virginian bank of the Potomac River near the bustling ports of Georgetown, Maryland and Alexandria, Virginia. The caveat that brought this case to the United States Supreme Court was that Christ Church and its glebe now stood in the new capital city, Washington, DC (see Figure 2). ${ }^{84}$ Christ Church sought an act of incorporation from Congress in order to stave off the seizure of their property. ${ }^{85}$

84. The Christ Church glebe stood in the part of Fairfax County, Virginia that was ceded to form Washington, DC. See An Act Concerning the District of Columbia, 2 Stat. 103 (1801). Michael McConnell suggests that the vestry's decision to bring Terrett in federal court was a shrewd strategy for the case to be heard by a friendlier Federalist judge, but this assertion overlooks the court battle in Turpin. The federal court was a last resort for the Alexandria vestry, and they brought the suit only after Madison's veto and the Fairfax Overseers' attempt to seize the glebe. McConnell, "The Supreme Court's Earliest Church-State Cases," 13.

85. "An Act Incorporating the Protestant Episcopal Church in the town of Alexandria, in the District of Columbia," January 1811. The Debates and Proceedings in the Congress of the United States, Vol. 22, 105. 


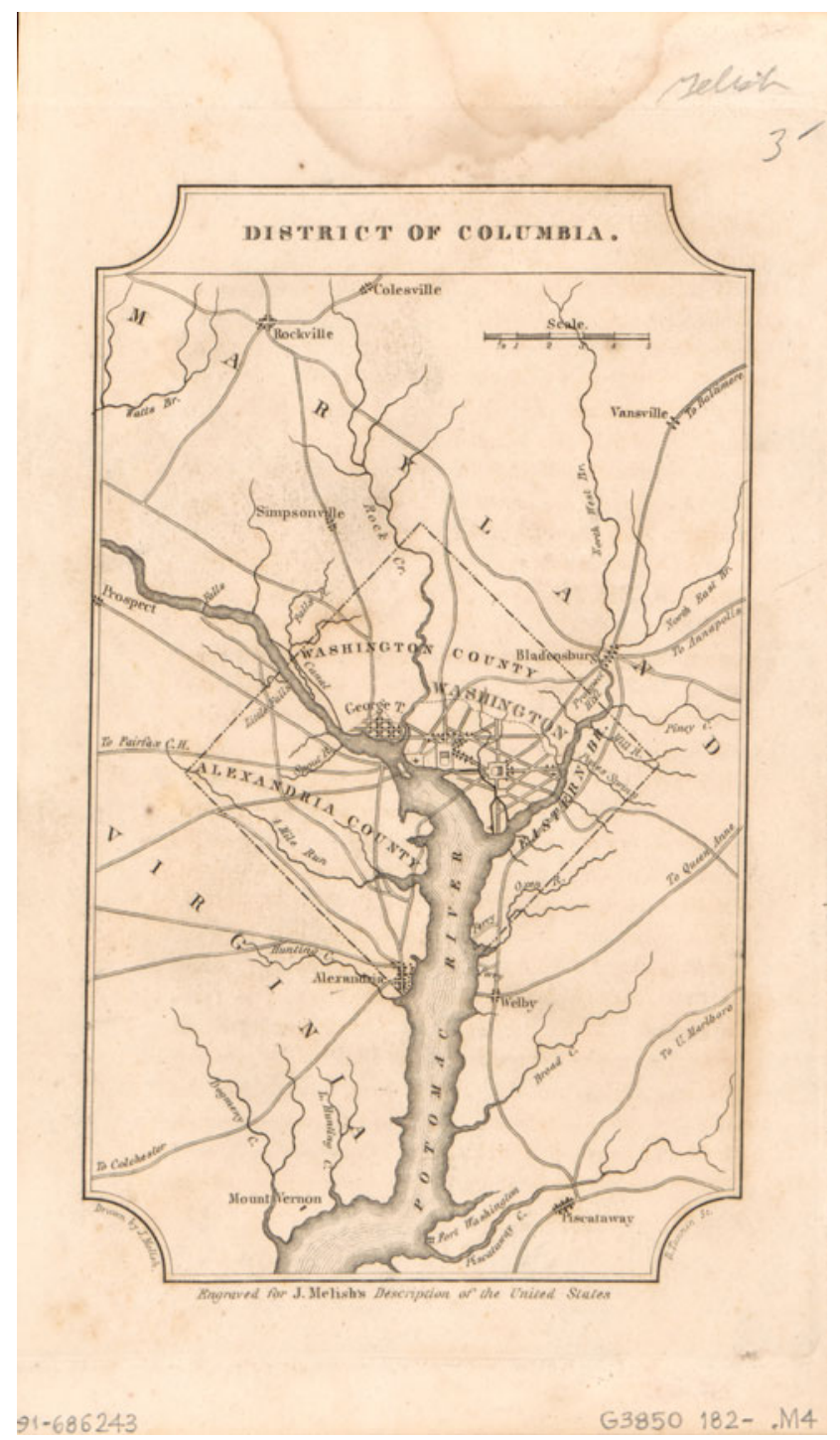

Figure 2. In 1801, Maryland and Virginia ceded land to the federal government to create the District of Columbia. 31 square miles on the southwestern bank of the Potomac River, formerly part of Fairfax County, VA, became Alexandria County, DC. Christ Church stood in the town of Alexandria at the southernmost point of the federal district, and its glebe lands lay to the northwest in the county. Library of Congress, Geography and Map Division. Melish, John, and Benjamin Tanner. District of Columbia. [Philadelphia? s.n., 182-?, 1820] Map. https://www.loc.gov/ item/91686243/. 
However, President James Madison vetoed the resulting Act of Incorporation in 1811. Madison explained that the law, which incorporated the church and laid out rules for the ecclesiastical corporation's government, "exceeds the rightful authority to which governments are limited by the essential distinction between civil and religious functions and violates in particular the article of the Constitution of the United States which declares that "Congress shall make no law respecting a religious establishment." ${ }^{\circ 6}$ Madison had been convinced by Virginia's evangelicals that incorporation was a form of religious establishment. ${ }^{87}$ After leaving office, he would elaborate on the threat posed by propertied religious corporations in his Detatched Memoranda. The "indefinite accumulation of property from the capacity of holding it in perpetuity" would enable ecclesiastical corporations to swallow government, and he argued that "the power of all corporations, ought to be limited in this respect." ${ }^{88}$ Madison articulated a far-reaching vision of non-establishment at the national level by insisting that any form of religious incorporation not only entangled church and state but also threatened liberty. ${ }^{89}$

After Madison's veto, the Fairfax County, VA Overseers of the Poor moved forward with the seizure of Christ Church's property. At this point, Christ Church's vestry sued in equity to prevent the sale of its property. Several of the same issues that Tucker had answered in Turpin re-emerged: was the vestry of Christ Church a corporation and, if so, did it hold legal title to the glebe lands? Did a state legislature have the right to seize the property of the parish? The court also had to answer the additional jurisdictional question of whether a county in Virginia could confiscate land in Washington, DC under a state law.

86. "From James Madison to the House of Representatives, 21 February 1811," Founders Online, National Archives. https://founders.archives.gov/documents/Madison/03-03-020233 (accessed November 24, 2020).

87. Michael McConnell characterized Madison's veto message as "narrow" and suggested that this veto "should not be interpreted as opposing all incorporations of religious bodies." However, Madison objected to the bill because it outlined "sundry rules and proceedings relative purely to the organization and polity of the church incorporated." Therefore, any act of incorporation for a religious society that specified the rules of internal denominational governance would have qualified as a form of religious establishment under the terms that Madison laid out in this veto message. Such sweeping logic was far from narrow and would have challenged numerous state acts of incorporation on the books in 1811. See McConnell, "The Supreme Court's Earliest Church-State Cases," 15; and "From James Madison to the House of Representatives, 21 February 1811," Founders Online.

88. James Madison, "Detatched Memoranda, ca. 31 January 1820," Founders Online.

89. Philip Hamburger, Separation of Church and State (Cambridge, MA: Harvard University Press, 2009), 182n66. 
Turpin and Terrett were not only connected by the similarity of their circumstances but also by the presence of Justice Bushrod Washington on the Supreme Court. When working in private practice in Richmond in 1797, Justice Washington had been quietly consulted about the possibility of glebe confiscation. He offered an uncompromising defense of the vested rights of parishes to their property. ${ }^{90}$ Washington's prior connection to the case has gone unnoticed by constitutional scholars, and he did not recuse himself from Terrett despite his earlier involvement.

Neither Marshall nor Washington, the two Virginian justices, spoke on behalf of the Court in Terrett. Instead, New Englander Justice Joseph Story authored the Court's opinion, which distanced the decision from the decades of rancorous debate over the glebes in Virginia (indeed, distanced it so thoroughly that the essential prologue to Terrett has often been overlooked). ${ }^{91}$ Although Story acknowledged that the questions presented in Terrett were "of much delicacy," his opinion was anything but delicate. Virginia's Glebe Act exhibited an "embarrassing" disregard for "the rights and property" of the Episcopal Church. Tucker's decision in Turpin had trounced private property rights and threatened the foundation of all corporations. $^{92}$

Justice Story rejected the view that the Revolution had made the church's property into a public asset. Such a logic would unravel all pre-Revolutionary property claims, including "the property of any other corporation created by the royal bounty or established by the legislature" and undermine "the inheritances of every man in the state." "It made no difference that Virginia's parishes had secured their assets under common law and not through royal grant or legislative charter. The state had no claim on the property of the former established church, which was still vested in its parishes. The dissolution of royal government had not affected the vested property of vestries or any corporate bodies. The significance of Story's conclusions can only register once vestries are properly recognized as customary corporations. Story's discussion of colonial corporations in Terrett reveals one the most important links to Dartmouth College because he explicitly mentioned royal grants alongside customary corporations. ${ }^{94}$

90. Bushrod's Washington's 1797 opinion about the glebe lands is quoted in Mays, Edmund Pendleton, 2:404n14.

91. For more on Story's legal career, see Newmeyer, Supreme Court Justice Joseph Story.

92. Terrett v. Taylor, 13 U.S. (9 Cranch) (1815), 43, 48.

93. Terrett v. Taylor, 13 U.S. (9 Cranch) (1815), 50.

94. Ibid. Because previous accounts of Terrett ignore customary incorporation, they also overlook the significance of Story's discussion of royal grants and the durability of pre-Revolutionary corporations. See White, The Marshall Court, 608-11; Ely Jr., "The Marshall Court and Property Rights: A Reappraisal," 1049-50; McConnell, "The 
But Story insisted that the status of parishes in 1776 was beside the point. Since independence, the Virginia legislature had guaranteed the Episcopal Church its property in five separate statutes and formally incorporated the church in $1784 .{ }^{95}$ With these acts, the question of whether or not the church's incorporation had survived the Revolution no longer mattered. The state had "vested an indefeasible and irrevocable title" to the church to all parish property in $1776 .^{96}$ Then, it "expressly" conferred incorporation to "the minister and vestry, and, in case of a vacancy, the vestry of each parish respectively and their successors forever" and affirmed their title to all "the property of the late Episcopal church" when it chartered the Episcopal Church. ${ }^{97}$ The legislature retained some power over public corporations such as a town, city, or the parish of the established church but only abuse could jeopardize the rights of a private corporation and then only after a judicial judgment. ${ }^{98}$ Story staked out a significant distinction between public and private corporations by insulating private corporations from legislative intrusion. ${ }^{99}$ Once the state had conferred incorporation on the Episcopal Church in 1784, parishes were undoubtedly private corporations and beyond the reach of the legislature.

In short, Story treated the post-1784 parish like any other private corporation. He had no time for Tucker's framing of the dissolution of parishes in Turpin as part of the long march of religious reformation. For Story, Virginia's statutes first incorporating and then undoing incorporationand ultimately vesting parish property in the commonwealth-were "utterly inconsistent with a great and fundamental principle of a republican government, the right of the citizens to the free enjoyment of their property." 100 Virginia's Glebe Act was "not, therefore in our judgment, operative so far as to divest the Episcopal church of the property acquired, previous to the revolution, by purchase or by donation."101

Dueling interpretations of corporations ultimately underlay the differences between Tucker's and Story's rulings in Turpin and Terrett. Tucker's opinion had distinguished between the property rights of private

Supreme Court's Earliest Church-State Cases," 15-18; Benjamin F. Wright, Jr., The Contract Clause of the Constitution (Cambridge, MA: Harvard University Press, 1938), 38; and Currie, The Constitution in the Supreme Court, 138-41.

95. Virginia, Revised Code, v. 1, 79.

96. Terrett v. Taylor, 13 U.S. (9 Cranch) (1815), 50.

97. Terrett v. Taylor, 13 U.S. (9 Cranch) (1815), 43, 47.

98. Terrett v. Taylor, 13 U.S. (9 Cranch) (1815), 51-52.

99. Newmeyer characterizes Terrett as a significant development in the public-private distinction in American law. Newmeyer, Supreme Court Justice Joseph Story, 132-33.

100. Terrett v. Taylor, 13 U.S. (9 Cranch) (1815), 51-53.

101. Terrett v. Taylor, 13 U.S. (9 Cranch) (1815), 43, 50-52. 
persons and corporations. Story made no such exception but instead declared, "the dissolution of the regal government no more destroyed the right to possess or enjoy this property than it did the right of any other corporation or individual to his or its own property." ${ }^{\text {102 }}$ In Story's rendering, a private corporation carried out the rights of its constituent members, and therefore, any state incursion on the powers of a private corporation amounted to an attack on the fundamental rights of private citizens.

Story also dismissed the argument that the legislature had a constitutional duty to repeal incorporation in order to protect religious freedom. In one of the earliest Supreme Court discussions of the First Amendment's religion clauses, Story castigated the Virginian legislature, and implicitly the sitting President, James Madison, for equating incorporation with religious establishment. ${ }^{103}$ Madison's veto message and Tucker's Turpin opinion had made entanglement between church and state the basis for their definition of religious establishment. Story, however, offered a definition of religious establishment rooted in exclusivity. Virginia's Constitution prohibited "a religious establishment which should have exclusive rights and prerogatives, or compel the citizens to worship under a stipulated form or discipline, or to pay taxes to those whose creed they could not conscientiously believe" but "the free exercise of religion cannot be justly deemed to be restrained by aiding with equal attention the votaries of every sect."104 Story's opinion highlighted that Virginia's rejection of any form of religious incorporation diverged sharply from other states, where general statutes of incorporation for religious societies were common. This discussion of religious freedom was not tangential but was essential to Story's line of argument. In order to dismiss any constitutional basis for Virginia's revocation of incorporation, he had to argue that nothing in the acts incorporating the church and confirming its property infringed the right to free exercise or constituted an established religion

Story upbraided Virginia's disestablishmentarian laws for treading "upon the principles of natural justice, upon the fundamental laws of every free government, upon the spirit and the letter of the constitution of the United States, and upon the decisions of most respectable judicial tribunals." ${ }^{105}$ Story was certainly vague in Terrett about which clause of

102. Terrett v. Taylor, 13 U.S. (9 Cranch) (1815), 50.

103. Currie discusses Terrett as one of the earliest expositions on the Establishment Clause. Currie, The Constitution in the Supreme Court, 140-41.

104. Terrett v. Taylor, 13 U.S. (9 Cranch) (1815), 49.

105. Terrett v. Taylor, 13 U.S. (9 Cranch) (1815), 52. 
the Constitution Virginia's laws violated, and scholars have often suggested that natural law was the true rationale for his decision. ${ }^{106}$ But in his Commentaries on the Constitution, Story later included Terrett in his discussion of the Contract Clause and Article VI, Section 1. ${ }^{107}$ Once the vestry is properly regarded as a pre-Revolutionary corporation, the decision's basis in the Constitution comes into clearer focus, as does its close connections in Dartmouth College. The vestry of Fairfax Parish had purchased its glebe in 1770 from Daniel Jennings and his wife using money raised from parishioners. ${ }^{108}$ Although the corporate existence of colonial parishes rested on common law, Story argued that the Revolution had in no way impaired the corporation's standing or interfered with the title to this property. Moreover, numerous pieces of legislation, including the 1784 Act of Incorporation and the 1786 Act of Repeal, had expressly affirmed vestries' titles to glebes. These laws guaranteeing the parish's "irrevocable" rights to its property had been unconstitutionally revoked by an overeager legislature. ${ }^{109}$

After dwelling at great length on the unconstitutionality of Virginia's statutes, Story ultimately offered one "farther objection" to uphold the vestry's claim. ${ }^{110}$ Because the Glebe Act had been passed after Christ Church and its glebe had become part of Washington, DC, Fairfax County officials lacked any power to seize the glebe. This jurisdictional argument could have been invoked at any point in the ruling to throw out Fairfax County's claim to the glebe lands. Instead, Story saw this case as an opportunity to articulate the power of private corporations and therefore chose not to address the jurisdictional question until he had laid out a detailed critique of Virginia's disestablishmentarian program. Justice Story attacked Virginia's state laws at great length but this narrower jurisdictional holding offered Virginia some room to sidestep the ruling.

Although Story never mentioned Turpin v. Lockett, his opinion systematically excoriated its rationale. His ruling declared two Virginian laws inoperative and contradicted Madison's interpretation of the 1776

106. White, The Marshall Court, 609, 611; Sylvia Snowiss, Judicial Review and the Law of the Constitution (New Haven, CT: Yale University Press, 1990), 136; and Currie, The Constitution in the Supreme Court, 141.

107. Joseph Story, Commentaries on the Constitution of the United States (Boston: Hilliard, Gray, and Company, 1833), 3:258, 260, 269, 533, 691.

108. For details of the purchase, see Nan Netherton, Donald Sweig, Janice Artemel, Patricia Hickin, and Patrick Reed, Fairfax County, Virginia: A History (Fairfax, VA: Fairfax County Board of Supervisors, 1978), 71.

109. Terrett v. Taylor, 13 U.S. (9 Cranch) (1815), 50.

110. Terrett v. Taylor, 13 U.S. (9 Cranch) (1815), 52. 
Virginian Constitution, the United States Constitution, and the Bill of Rights, all of which the sitting president had helped draft. The Court held that the Revolution had not affected the corporate standing of the parish and affirmed that incorporation, once granted, could not simply be revoked by the legislature. The vestry had won their case. Terrett had outlined many of the key ideas associated with Dartmouth College v. Woodward, and its role as a central precedent makes sense when the parish is rightfully understood to be a colonial corporation.

What did Chief Justice Marshall, who had personally taken part in Virginia's disestablishment, make of Terrett? Story wrote that Terrett was decided by a "majority," which suggests that at least one of the four justices present for the case (Livingston, Marshall, Washington, and Duvall) disagreed with Story's opinion. ${ }^{111}$ There is ample evidence to conclude that Marshall acquiesced with Story's rationale in Terrett. ${ }^{112}$ Not only had the chief justice grown up under the established church, his father had also served as a vestryman and signed property deeds on behalf of his parish. ${ }^{113}$ Marshall would have intimately understood the colonial parish's status as a common law corporation from such a vantage point. As a legislator, Marshall had voted to incorporate the Protestant Episcopal Church in 1784 and argued that the legislature did not have adequate grounds in 1786 to revoke its charter. After the repeal of incorporation, Marshall voted in support of a resolution framing the conflict as a matter of "private

111. Of the four Justices, Duvall seems most likely to have dissented. Washington cited the Terrett decision in his opinions in Trustees of Dartmouth College v. Woodward (1819) and Society for Propagation of the Gospel v. Town of New Haven (1823). Livingston signed onto Story's and Washington's decisions in Dartmouth that cited Terrett. Given the overwhelming evidence that Marshall agreed with the logic of Terrett, we are left to assume that Duvall alone dissented in Terrett. Duvall is perhaps best known for his reticence on the Court, and therefore, it seems unsurprising that he left no explanation of his dissent. See Society for Propagation of the Gospel v. Town of New Haven, 21 U.S. 464 (1823), 481-82; and Trustees of Dartmouth College v. Woodward, 17 U.S. 518 (1819), 664-66. For more on Duvall, see White, The Marshall Court, 321-27.

112. Terrett v. Taylor, 13 U.S. (9 Cranch) (1815), 55. The confusion over which justices joined Story's opinion in Terrett is widespread in the literature. Several sources state either that the decision was unanimous or specifically note that Marshall joined Story's opinion. See Mays, Edmund Pendleton, 2:404n14; Albert J. Beveridge, The Life of John Marshall (Boston: Houghton Mifflin, 1919) 4:243; and Thomas E. Buckley, "After Disestablishment: Thomas Jefferson's Wall of Separation in Antebellum Virginia," The Journal of Southern History 61 (1995): 450n13. To err on the side of caution, this article understands the term "majority" in the text of the decision to be a reflection of non-unanimity.

113. Beveridge, The Life of John Marshall, 1:52n3. 
property," reaffirming the vested rights of parishes, and preventing future discussion of glebe confiscation. ${ }^{114}$ The evidence from Marshall's legislative career overwhelmingly suggests that he would have joined Story's decision in Terrett.

Another clue to Marshall's views can be found in a closely related case, Town of Pawlet v. Clark (1815), which the Court heard just a few weeks after Terrett. Pawlet arose in the only other state that confiscated Anglican Church property, Vermont, where the legislature passed statutes in 1794 and 1805 empowering towns to seize glebe lands for schools. ${ }^{115}$ Story wrote on behalf of the Court to uphold Vermont's laws. Although it may seem contradictory for the Court to reject Virginia's glebe confiscation policy while approving Vermont's plan, Story's decision in Pawlet relied on the same logic as Terrett. The divergent outcomes in the two cases lay in the distinctions between the Anglican Church in Virginia and in Vermont before the Revolution. Virginia's seizure of the glebes was held unconstitutional because the legislation siezed vested property from longstanding corporate bodies. It was a different story in Vermont where there had been no operational Anglican Church before the Revolution. Without parsons, vestries, or churchwardens, there were no corporations to claim the property before the Revolution. Title to the glebe lands remained vested in the crown and passed to the new sovereign, the state of Vermont, at the outbreak of the Revolution. Story's reasoning in the two cases was identical; namely, that the state could not take vested property from corporate bodies. The Pawlet decision does not record Marshall's support, but the Chief Justice endorsed Story's rationale just a few years later in his decision in Trustees of Philadelphia Baptist Ass'n v. Hart's Executors (1819). ${ }^{116}$ Ultimately, the Court's decisions in Terrett and Pawlet affirmed the rights of corporations and provided ideological scaffolding for yet another disestablishmentarian case, Dartmouth College.

114. November 27, 1789, Journal of the House of Delegates of the Commonwealth of Virginia (Richmond, VA: 1828), 83-84, 113.

115. Town of Pawlet v. Clark, 13 U.S. 292 (1815). For a comparison of the two policies of confiscation, see Gordon, "The Landscape of Faith."

116. Eric Michael Mazur argues that Marshall "relied on (but did not cite) Story's reasoning" in Terrett and Pawlet in his decision in Trustees of Philadelphia Baptist Ass'n v. Hart's Executors (1819). Mazur, "Religion and the Earliest Supreme Court Justices, 1789-1911," in The Wiley Blackwell Companion to Religion and Politics in the U.S., ed. Barbara McGraw (Malden, MA: Wiley Blackwell, 2016), 130. 


\section{Disestablishment and Dartmouth College}

Dartmouth College, so often framed as a landmark case because it enabled the rapid transformation of the American economy, was itself the byproduct of another sweeping transformation, the disestablishment of religion. Although scholars have convincingly argued that the emergence of statutory frameworks for business and religious corporations were "distinct" processes, litigation during religious disestablishment ultimately enshrined the rights of business corporations and made them powerful vehicles for commercial growth. ${ }^{117}$ Dartmouth College crystallized the implicit logic of Terrett by holding that all charters were contracts and thus offered robust protections to all private corporations.

Like Turpin, Terrett, and Pawlet, the dispute at the center of Dartmouth College emerged from an acrimonious disestablishmentarian dispute. ${ }^{118}$ A theological rift between the college's more liberal president and its evangelical trustees became politicized when the newly elected legislature modified the college's charter in 1816. The state took control of the school's governance and established Dartmouth University as a nonsectarian, public university in place of the orthodox college. Dartmouth's former trustees refused to concede and sued in 1817 to challenge the legislation. The case pitted the ascendant Democratic Republicans in the statehouse who supported disestablishment against the Congregationalists on Dartmouth's Board of Trustees.

Daniel Webster, who argued on behalf of his alma mater, invoked Terrett repeatedly in his arguments before the Court. The 1815 decision had already affirmed that the legislature could not modify or repeal acts creating private corporations. Webster suggested that "if, therefore, it has been shown, that this college is to be regarded as a private charity, this case is embraced within the very terms of that decision [Terrett]." ${ }^{119}$ Although Americans celebrate Dartmouth College as the case that asserted these rights, Webster suggested that the Court had already laid this groundwork 4 years earlier in Terrett when it ruled that Virginia could not revoke the charter of a private corporation.

Justice Bushrod Washington's concurring opinion echoed Webster's oral arguments. Not only did Washington cite Blackstone's distinction between private and public corporations, he also called attention to the fact that the Court had already set down the differences by quoting at

117. Gordon, "The African Supplement," 389-90n8.

118. For an excellent discussion of the conflict in Dartmouth, see McGarvie, One Nation Under Law, 152-89.

119. Trustees of Dartmouth College v. Woodward, 17 U.S. 518 (1819), 591-92. 
length from Story's opinion in Terrett. He wrote that in Terrett and Dartmouth College, "it is most obvious, that the effect of [the states'] laws is to abolish the old corporation, and to create a new one in its stead." He asked rhetorically, "In what respects do [these cases] differ?" None at all, he concluded. In both instances, "the contract has been altered, without the assent of the corporation, its obligations have been impaired."120 Washington, who had once called Virginia's glebe confiscation a "humiliation," drew together the Virginia Glebe Act and the actions of the New Hampshire legislature by labelling both as laws that were "repugnant" to the Constitution in his opinion Dartmouth College. ${ }^{121}$

Justice Story, in another concurring opinion, also pointed to his earlier decision in Terrett. Whereas Terrett specifically focused on the status of common law corporations and acts of incorporation, the 1815 decision had suggested that royal grants had likewise survived the Revolution. Story took the opportunity to rule affirmatively on the matter in Dartmouth College when asserting that the Revolution had not destroyed vested rights of property and arguing that the legislature did not have the right to seize the property of a corporation. ${ }^{122}$ The justice also returned to the distinction between private and public corporations, just as he had in Terrett. Both of his opinions relied on similar language, precedents, and examples. Whereas Terrett afforded Story an initial opportunity to evaluate the vested rights of corporations, Dartmouth College allowed the Court to establish the sanctity of corporate charters.

But the opinion of the Court, authored by Chief Justice Marshall, did not cite Terrett. Marshall included no citations at all in his decision, save two references to Blackstone and an oblique statement that his opinion rested on "the former decisions of this Court." 123 The absence of a citation to Terrett in the text of the decision, then, cannot be taken to mean that the chief justice did not link the two cases. ${ }^{124}$ The omission of any precedent

120. Trustees of Dartmouth College v. Woodward, 17 U.S. 518 (1819), 664-65.

121. Mays, Edmund Pendleton, 2:404n14; and Trustees of Dartmouth College v. Woodward, 17 U.S. 518 (1819), 664.

122. Trustees of Dartmouth College v. Woodward, 17 U.S. 518 (1819), 707, 695.

123. Trustees of Dartmouth College v. Woodward, 17 U.S. 518 (1819), 633-34, 650. Newmeyer stated that Marshall "cited" Terrett in Dartmouth College, but does not elaborate any further. Newmeyer may have been referencing this ambiguous line about the Court's prior decisions. Newmeyer, Supreme Court Justice Joseph Story, 132.

124. Numerous scholars have observed Marshall's penchant for excluding citations from his decisions. See David S. Schwartz, The Spirit of the Constitution: John Marshall and the 200-Year Odyssey of McCulloch v. Maryland (New York: Oxford University Press, 2019), 60; Hobson, The Great Chief Justice, 181-83; Wicek, Liberty under Law, 32-33; David P. Currie, The Constitution in the Supreme Court: The First Hundred Years, 1789-1888 (Chicago: The University of Chicago Press, 1992), 196. 
from Marshall's opinion requires looking beyond the decision to piece together what informed his rationale.

Marshall's involvement in Virginia's disestablishment offers a compelling answer to this puzzle and reveals the relevance of Terrett and its backstory to Dartmouth College. Marshall had so many connections to Virginia's disestablishment that it would have been impossible for the circumstances of Turpin and Terrett not to have shaped his thinking about Dartmouth College. Marshall had invoked the irrevocable nature of charters as far back as 1786 when he, Randolph, and Madison discussed under what circumstances the legislature could permissibly strip the Episcopal Church of its incorporation. Marshall voiced a commitment to protecting vested rights and preventing legislative intrusion by voting to support the resolution against glebe confiscation in 1789. The fight over incorporation and glebes during Virginia's disestablishment had induced Marshall to assert his views on charters, corporations, and vested property rights. The arguments underlying the Dartmouth College decision reflected and developed these points into the landmark statement on corporate rights that it has become.

Marshall's decision in Dartmouth College endorsed many of the same principles as Story's opinion had in Terrett. Dartmouth College, like Terrett, distinguished between public and private corporations and insisted on the insulation of private corporations from the legislature. ${ }^{125}$ Marshall declared in Dartmouth that "all contracts and rights respecting property, remained unchanged by the revolution," which echoed Story's statement in Terrett that "the dissolution of the regal government no more destroyed the right to possess or enjoy this property than it did the right of any other corporation or individual to his or its own property." ${ }^{26}$ The significant difference between these statements, of course, lay in the Marshall's use of the word "contract." Marshall expressly grounded his decision in the Contract Clause by framing all corporate charters as contracts. Although built on the same logical framework as Terrett, Dartmouth's holding explicitly embraced all private corporations in its holding.

When Marshall wrote in Dartmouth College that "almost all eleemosynary corporations, those which are created for the promotion of religion, of charity or education, are of the same character...[t]he law of this case is the law of all," his words encompassed not only a small college in New

125. Newmeyer suggests that Dartmouth "complete[d] the formulation of the publicprivate doctrine begun in Terrett." Newmeyer, Supreme Court Justice Joseph Story, 132. Terrett v. Taylor, 13 U.S. (9 Cranch) (1815), 51-52; and Trustees of Dartmouth College v. Woodward, 17 U.S. 518 (1819), 635-39.

126. Trustees of Dartmouth College v. Woodward, 17 U.S. 518 (1819), 651; and Terrett v. Taylor, 13 U.S. (9 Cranch) (1815), 50. 
Hampshire but also a contested church in the nation's capital. He asked rhetorically whether "the objects of religion, charity, and education were of so little estimation in the United States, that contracts for their benefit" might not be respected as those of other private corporations. Although specifically referring to the College, these words brought all benevolent institutions to the foreground, and indeed all private corporations. With this sweeping assessment, Marshall drew together the earlier decision in Terrett with Dartmouth College in protecting the rights of all corporations. $^{127}$

\section{Conclusion}

Perhaps it is not surprising that Terrett $v$. Taylor faded into obscurity. Virginia did not heed the decision and continued to seize glebe lands. In the 1820 s, Virginia's vestries mounted another challenge to the 1802 Glebe Act citing Terrett. In a remarkable twist of fate, St. George Tucker's son, Henry St. George Tucker, presided over the case, Selden v. Overseers of the Poor of Loudoun, as chancellor of the Winchester Chancery Court in 1830. The younger Tucker upheld his father's decision in Turpin and declared that "the question in this case is not touched by the constitution of the United States. . this is a subject over which the supreme court of the United States have no manner of jurisdiction." 128 But Henry St. George Tucker's Selden opinion did cite Dartmouth College to argue that Virginia's church had been fundamentally a public institution and therefore under complete legislative control. ${ }^{129}$ In a stroke of irony, the distinction between private and public corporations that Terrett had helped forge in American law was now being wielded against parishes. Tucker relied on Dartmouth College's distinction between private and public corporations while flatly rejecting the rationale of Terrett, and allowed glebe confiscation to proceed. Virginia's refusal to recognize Terrett underscored the limited practical significance of the case.

But looking at this series of cases together-starting with Turpin, moving next to Terrett and then considering Dartmouth College-offers several important insights to scholars. First, these cases reveal the stark disagreements among early American legal theorists about the fundamental

127. Trustees of Dartmouth College v. Woodward, 17 U.S. 518 (1819), 645-46.

128. Henry St. George Tucker, "The Opinion of Chancellor Tucker in the Case of Selden and Others against the Overseers of the Poor of Loudoun and Others," in Commentaries on the Laws of Virginia, 3rd edition (Richmond:Printed by Shepherd \& Colin, 1846), 453.

129. Ibid., 454. 
nature of corporations, the rights of corporations in relation to the legislature, and the purpose of corporations in society. The Revolution upended the relationship between the governed and their government and threw the doors wide open to challenging a range of inherited legal doctrines and customs. Monarchy, aristocracy, religious establishment, entail, primogeniture, and a host of cornerstones of pre-Revolutionary law fell victim to this movement. In Virginia, customary corporations and irrevocable charters were likewise attacked as an un-republican vestige of legal favoritism. Ultimately, the defense and definition of the corporation that was cemented in Dartmouth College emerged from this process of cultural turmoil and settled some of the most hotly contested legal questions left over from the rupture of revolution.

Second, reading these cases together underscores why disestablishment was an essential context for the rise of the corporation. The separation of church from state raised difficult questions about how to remove the legal advantages of the former religious establishment, including customary incorporation, and whether it was permissible to strip private corporations of their charters and property. Adjudicating the bulwark of rights that protected corporations was bound up in trying to dismantle the system of religious establishment that so many had come to view as fundamentally anti-republican. As state legislatures, courts, and ordinary people answered these queries, they grappled with and ultimately set forth the rights of private corporations in the new nation.

Finally, these cases clarify why Dartmouth College set such an important precedent in the Early Republic. The Court may have offered an ideological defense of customary incorporation in Terrett, but Virginia's continued refusal to abide by the decision underscored the weakness of common law incorporation. In contrast, Dartmouth afforded power and protection to all chartered corporations. Together, these cases reveal that one of the most significant legal outcomes of disestablishment was the ascendance of the charter. Dartmouth College established the security of contract over custom and led charters to supersede any other legal framework for incorporation. 